\title{
INNOVATIVE CONSTRUCTION MATERIAL BASED ON AERATED CERAMICS
}

\author{
Konstantin Dmitriev ${ }^{1}$, Victor Zverev ${ }^{2}$ \\ ${ }^{1}$ INFOSMIT Co. Ltd, \\ Finlyandskaja ul. 16, k. 1, Kolpino, St. Petersburg, Russia \\ ${ }^{2}$ Saint Petersburg State University of Architecture and Civil Engineering \\ Vtoraja Krasnoarmejskaja ul. 4, St. Petersburg, Russia \\ 11dm-konstantin@mail.ru, ${ }^{2}$ centeririna@spbgasu.ru
}

\begin{abstract}
The study looks at the production of effective construction materials based on clay rocks of various mineral and chemical compositions. A method for the manufacturing of aerated ceramic materials and products with the specified average density is described; results of their structure analysis, as well as physical and mechanical characteristics of aerated ceramic samples are presented.

The main production stages for the creation of a cellular structure of a ceramic shard are presented, and the prospects of aeration technology for clay masses for the production of a non-combustible material that allows the construction of wall enveloping structures with high strength and thermophysical parameters is proved.
\end{abstract}

Keywords
Clay, aeration, cellular ceramics, ceramic slurry, structure.

\section{Introduction}

Ceramic bricks and stones are basic wall materials widely used in private residential and multi-storey construction. Baked clay products are characterized with durability, fire resistance, environmental friendliness, architectural expression and certain physical and mechanical properties required for the construction of high reliability buildings and structures with optimum microclimate in premises (Zavadskiy et al., 2004).

The technology for the manufacturing of dense lightweight ceramic products has been known for a long time, but to ensure particular thermal and physical parameters of modern buildings, it is necessary to use effective heat insulating materials. Mineral wool and foamed polystyrene are the most popular among them. Both materials have certain advantages and disadvantages. Mineral wool is preferably used as heat insulation for building walls. Since this material shall not be exposed to direct atmospheric influences, construction engineers have to use various facade finishing systems.

However, their use leads to inevitable complications of construction compared to walls made of ceramic bricks or stones only. To ensure the homogeneity of wall heat and moisture transfer parameters, it is preferably to build walls with related construction materials, i.e. use dense ceramic bricks and highly porous ceramics simultaneously (Dmitryev, 2015).

\section{Methods for the production of cellular ceramics}

As for traditional wall ceramics, there are two basic ways to reduce the average density of products: removal of foaming agents and cavitation. Porous ceramic stones widely used in the construction practice can be obtained by the combination of several methods: generation of through cracks and introduction of pore-forming agents into the initial ceramic mass. This method allows for the reduction of fuel consumption, efficient product density decrease, use of industrial by-products, etc. Sawdust, coal, ash, foamed polystyrene, by-products of paper and coal industries, etc. are used as pore-forming agents (Rogovoy, 1974).

In foreign countries, the Poroton technology for manufacturing porous-hollow products, developed in Germany and Sweden more than 25 years ago (Rekitar, 1981; Boldyrev et al., 1980), has become widespread. The patent for manufacturing these products was purchased by 32 countries. Poroton products are manufactured by plastic molding and introduction of foamed polystyrene beads as burning addition. 


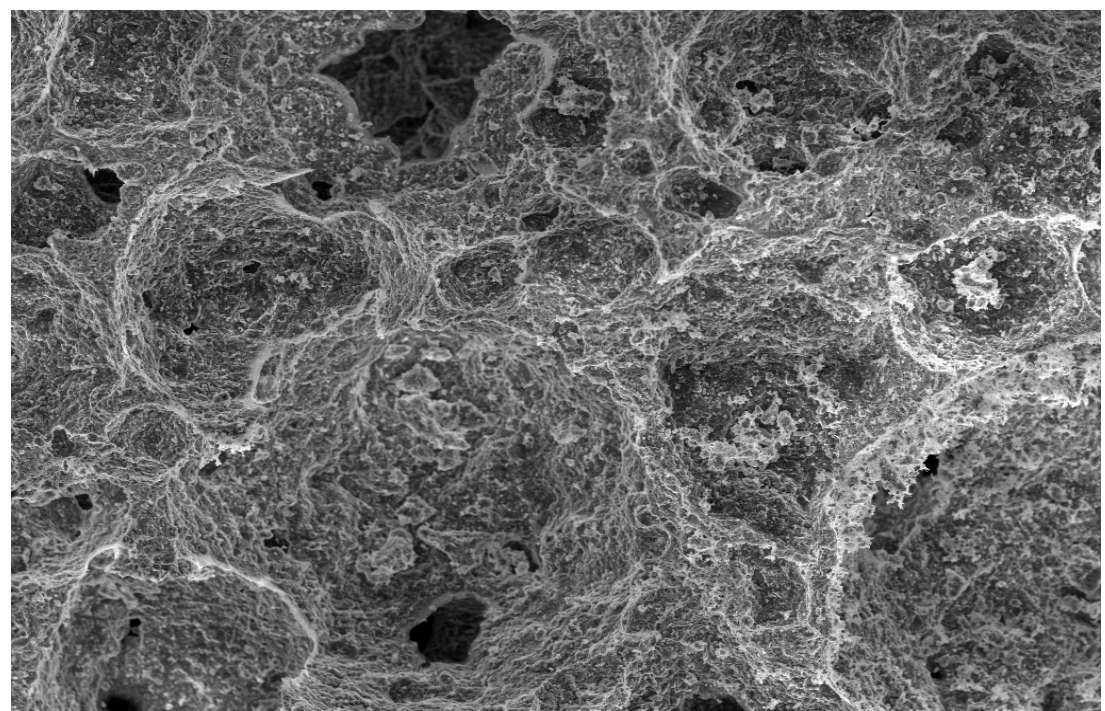

Figure 1. Fragment of the micro-porous structure of an aerated ceramic product made of Mix 1, division value $-20 \mu \mathrm{m}$

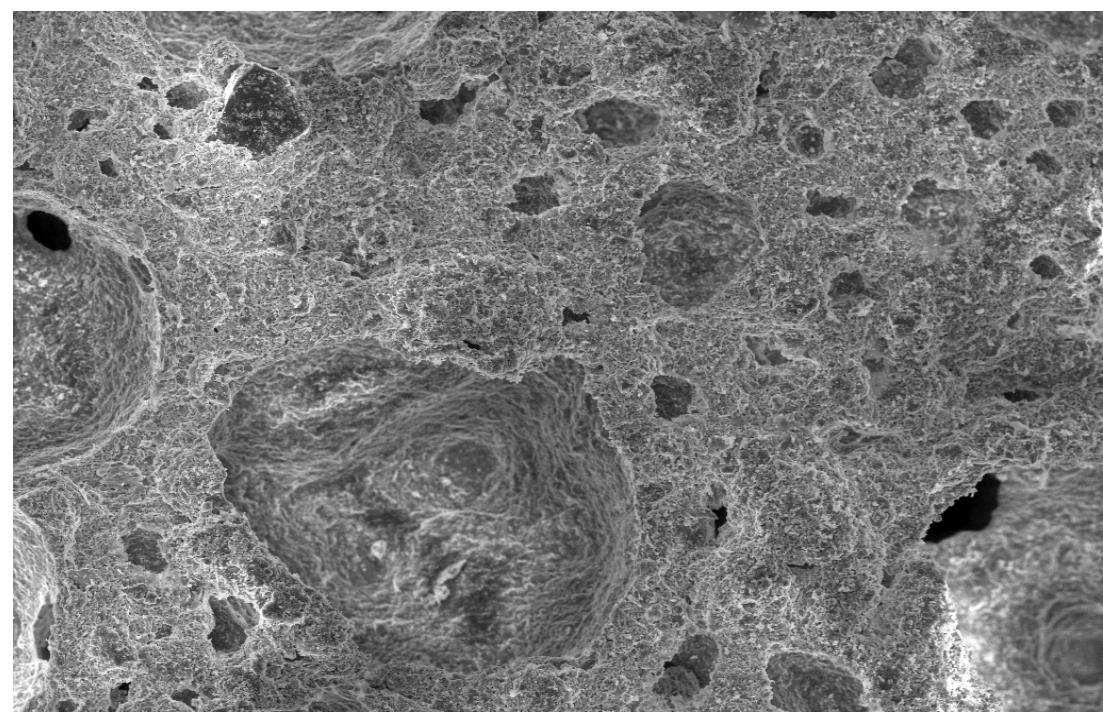

Figure 2. Fragment of the micro-porous structure of an aerated ceramic product made of Mix 2, division value $-20 \mu \mathrm{m}$

Besides, the method of gas generation with aluminum powder, as well as the method of foam formation using individually manufactured commercial foam as a foaming agent (Selivanov et al., 2013; Krutov and Gavrilyuk, 2012), are actively used and developed to obtain cellular structures. However, these methods have not come into common industrial use due to insufficient theoretical substantiation and practical background.

Analysis of literature and research data shows prospects for the development of the porous structure of a ceramic piece by the aeration of clay ceramic slurry in a high-speed mixer, based on modern advances in the ceramic industry and production of cellular concrete.

\section{Experimental setup}

Due to effective cooperation of the INFOSMIT testing laboratory and the Department of Technology of Building Materials and Metrology (Saint Petersburg State University of Architecture and Civil Engineering), practical and theoretical regulations in the field of clay slurry aeration and production of highly porous ceramic materials possessing high strength and thermal-physical properties were established.

The main features of the technology for the development of the cellular structure in a ceramic piece are the following:

- preparation of the following raw components: clay raw materials, electrolytes, thinning agents, reinforcing agents, pore-forming agents, and water.

- preparation of a raw mix in the form of slurry with a certain viscosity;

- pore formation (aeration) in slurry until the achievement of the required density by the clay mass;

- molding of the aerated clay mass into rigid molds using vibrating devices, if necessary;

- drying of the aerated mass until the achievement of the residual moisture content of less than $15 \%$, followed by cutting into work pieces; 
- heat treatment of prepared raw products;

- cooling, surface treatment, packaging and dispatch to the finished goods warehouse.

Slurry aeration is performed with forced air entrainment and its retention in the mass in the form of bubbles. Retaining of the cellular structure during drying is based on clay slurry coagulation. One of the main difficulties in the preparation of raw mixes and a production line is the variety of clay deposits establishing various approaches to the development of the composition, its rheological properties and basic production conditions.

The experiment is based on the use of clays from different deposits to produce aerated ceramic bricks with dimensions of $250 \times 120 \times 65 \mathrm{~mm}$.

The chemical composition of the used clays is shown in Table 1. The raw mix consists of the following components: sodium silicate (electrolyte), finely crushed aerated ceramic bricks (thinning agent), basalt fiber (reinforcing agent), synthetic foaming agent (pore forming agent), and process water. The clay component and thinning agent are pre-dried to $5 \%$ moisture content and grinded to powder with the maximum particle size of $0.16 \mathrm{~mm}$.

The ratio of components is given in Table 2 .

The above-mentioned mixes were selected to produce defect-free aerated ceramic bricks with the average density of $600 \mathrm{~kg} / \mathrm{m}^{3}$ and compression strength of at least 5.0 $\mathrm{MPa}$.

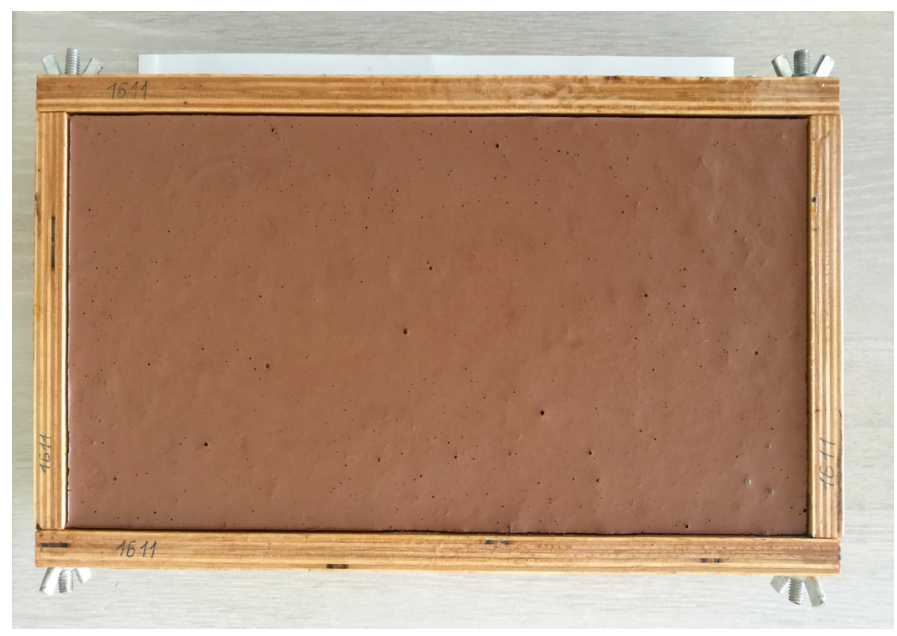

Figure 3. Appearance of the aerated clay mass made of Mix 1 during drying

Slurry preparation and aeration are carried out in a high-speed mixer with the propeller stirrer rotation frequency of $2100 \mathrm{rpm}$ to obtain the porous clay mass of the required density. The aeration time is 4 minutes.

The obtained aerated clay mass is portioned into rigid molds with sides, coated with an agent reducing adhesion of the laid aerated clay mass to the inner walls of the mold. The molded aerated clay mass is dried in drying chambers with the maximum heat-transfer medium temperature of $65^{\circ} \mathrm{C}$ until shrinkage completion and the moisture level of $7 \%$. Then products are heat treated at the max-

Table 1. Chemical composition of clays

\begin{tabular}{|c|c|c|c|c|c|c|c|c|}
\hline \multirow{2}{*}{ No. } & Clay type & \multicolumn{7}{|c|}{ Content of basic oxides } \\
\cline { 3 - 8 } & $\mathrm{SiO}_{2}$ & $\begin{array}{c}\mathrm{Al}_{2} \mathrm{O}_{3}+ \\
\mathrm{TiO}_{2}\end{array}$ & $\mathrm{Fe}_{2} \mathrm{O}_{3}$ & $\mathrm{CaO}$ & $\mathrm{MgO}$ & $\begin{array}{c}\mathrm{Na}_{2} \mathrm{O}+ \\
\mathrm{K}_{2} \mathrm{O}\end{array}$ & LOI \\
\hline 1 & $\begin{array}{c}\text { Brick clay from the } \\
\text { Novgorod Region }\end{array}$ & 56.45 & 18.23 & 6.92 & 4.71 & 2.22 & 4.14 & 7.33 \\
\hline 2 & $\begin{array}{c}\text { Brick clay from the } \\
\text { Leningrad Region }\end{array}$ & 62.19 & 16.56 & 6.14 & 1.53 & 4.05 & 4.94 & 4.59 \\
\hline 3 & $\begin{array}{c}\text { Brick loam from the } \\
\text { Udmurt Republic }\end{array}$ & 65.17 & 14.07 & 5.17 & 1.84 & 2.74 & 5.25 & 5.76 \\
\hline
\end{tabular}

Table 2. Composition of the raw mix

\begin{tabular}{|c|l|c|c|c|}
\hline \multirow{2}{*}{ No. } & \multicolumn{1}{|c|}{ Component } & \multicolumn{2}{c|}{ Contents } & Mix 3 \\
\cline { 3 - 5 } & & Mix 1 & - & - \\
\hline 1 & Brick clay from the Novgorod Region & 45.54 & - & - \\
\hline 2 & Brick clay from the Leningrad Region & - & - & - \\
\hline 3 & Brick loam from the Udmurt Republic & 0.48 & 0.45 & 0.17 \\
\hline 4 & Sodium silicate & 20.46 & 10.58 & 9.41 \\
\hline 5 & Crushed aerated ceramic bricks & 0.32 & 0.28 & 0.30 \\
\hline 6 & Basalt fiber & 0.67 & 0.73 & 0.65 \\
\hline 7 & Synthetic foaming agent & 32.53 & 32.91 & 29.02 \\
\hline 8 & Process water & & & \\
\hline
\end{tabular}


imum temperature of $980^{\circ} \mathrm{C}$ during 240 minutes. In this case, the time of temperature rise to the maximum level is 180 minutes; the cooling time is 360 minutes.

One of the engineering advantages of aerated ceramics production is an accelerated baking mode in comparison with solid ceramic products (the total baking time is less than 15 hours). Such acceleration is due to the high gas permeability of the dried raw material, allowing it to warm up to the maximum temperature faster, as well as due to the cellular structure with thin pore walls which do not require long-term heating at the maximum temperature (Morris et al., 2008; Gonzenbach et al., 2007).

Table 3. Main parameters of clay slurry and finished products

\begin{tabular}{|c|l|c|c|c|}
\hline No. & \multicolumn{1}{|c|}{ Parameter } & Mix 1 & Mix 2 & Mix 3 \\
\hline 1 & $\begin{array}{l}\text { Prepared slurry } \\
\text { density, kg/m }\end{array}$ & 1,684 & 1,726 & 1,703 \\
\hline 2 & $\begin{array}{l}\text { Aerated slurry } \\
\text { density, kg/m }\end{array}$ & 679 & 667 & 659 \\
\hline 3 & $\begin{array}{l}\text { Air shrinkage, } \\
\%\end{array}$ & 9.769 & 10.85 & 8.97 \\
\hline 4 & $\begin{array}{l}\text { Baking shrink- } \\
\text { age, } \%\end{array}$ & 1.84 & 2.45 & 2.18 \\
\hline 5 & $\begin{array}{l}\text { Average densi- } \\
\text { ty, kg/m }\end{array}$ & 606 & 598 & 595 \\
\hline 6 & $\begin{array}{l}\text { Compression } \\
\text { strength, MPa }\end{array}$ & 5.84 & 6.38 & 6.49 \\
\hline
\end{tabular}

Photos of the micro-porous structure of aerated ceramic bricks made of Mix 1 and Mix 2 were made using a
Tescan VEGA 3 SBH scanning electron microscope and are shown in Figures 1 and 2.

Main physical and mechanical parameters of clay slurry and corresponding aerated ceramic bricks are presented in Table 3.

Appearance of the molded aerated clay mass made of Mix 1 in the mold with dimensions of $287 \times 138 \times 75 \mathrm{~mm}$ is shown in Figure 3.

The described above method for the production of aerated ceramic products is implemented based on the closed cycle principle, where by-products are excluded: defective products are returned back to the production in the form of a thinning agent. The very principle of the development of the cellular structure in products is a new solution; it does not use standard binders as stabilizing additives, but reveals the natural properties of clays to the fullest extent possible.

\section{Conclusion}

The presented method of clay mass aeration makes it possible to regulate the density and strength of finished products in wide range; however, it is necessary to perform experiments on raw mix development, as well as on the selection of optimum drying and baking modes for each particular clay deposit.

In general, it is worth noting the high potential for the application of the technology for the production of aerated ceramics with high strength and thermal-physical parameters in production lines of existing ceramic plants with the aim to expand the range of products, as well as in the design of new manufacturing plants based on widely used clay raw materials without expensive components and complex production operations. 


\section{References}

Boldyrev, A.S., Dobuzhinskiy, V.I., Rekitar, Ya.A. (1980). Tekhnicheskii progress v promyshlennosti stroitelnykh materialov [Technological advances in the construction materials industry]. Moscow: Stroyizdat, p. 399. (in Russian)

Dmitryev, K.S. (2015). Peptizatciia glinistykh suspenzii v tekhnologii penokeramiki [Peptization of clay suspensions in the foam ceramics technology]. Fundamental Research, 10 (2), pp. 249-253. (in Russian)

Gonzenbach, U.T., Studart, A.R., Tervoort, E., Gauckler, L.J. (2007). Macroporous ceramics from particle-stabilized wet foams. Journal of the American Ceramic Society, 90 (1), pp. 19-22. DOI: 10.1111/j.1551-2916.2006.01328.x

Krutov, Yu.M., Gavrilyuk, A.Yu. (2012). Sposob polucheniia penokeramiki i izdelii iz nee [Method for the preparation of foam ceramics and foam ceramics products]. Patent No. 2469979 of the RF, MPK S $04 \mathrm{~V} 33 / 13$, S $04 \mathrm{~V} \mathrm{28/26,} \mathrm{S} 04 \mathrm{~V} \mathrm{38/00,} \mathrm{S} 04 \mathrm{~V}$ 40/00 [МПК С 04 В 33/13, С 04 В 28/26, С 04 В 38/00, С 04 B 40/00]. No. 2010130850/03, Application dd. 22.07.2010. Bulletin, 35, p.9. (in Russian)

Morris, G., Pursell, M. R., Neethling, S. J., Cilliers, J. J. (2008). The effect of particle hydrophobicity, separation distance and packing patterns on the stability of a thin film. Journal of Colloid and Interface Science, 327, pp. 138-144. DOI: 10.1016/j. jcis.2008.08.007

Rekitar, Ya. A. (1981). Tendentcii razvitiia stroitelstva $v$ vedushchikh kapitalisticheskikh stranakh [Trends in the development of construction in leading capitalist countries]. Moscow: Nauka, p. 336. (in Russian)

Rogovoy, M.I. (1974). Tekhnologiia iskusstvennykh poristykh zapolnitelei i keramiki [Technology of artificial porous fillers and ceramics]. Moscow: Stroyizdat, p.315. (in Russian)

Selivanov, Yu.V., Shiltsyna, A.D., Loginova, Ye.V., Selivanov, V.M. (2013). Syrevaia smes dlia izgotovleniia keramicheskikh teploizoliatcionnykh stroitelnykh materialov [Raw mix for the production of ceramic heat-insulating construction materials]. Patent No. 2484063 of the Russian Federation: MPK S 04 V 38/02, S 04 V 33/00 [MПK C 04 B 38/02, C 04 B 33/00]. Siberian Federal University. Application dd. 06.02.2012, No. 2012104036/03. Bulletin, 16. p. 6. (in Russian)

Zavadsky, V.F., Putro, N.B., Maksimova, Yu.S. (2004). Porizovannaia stroitelnaia keramika [Porous construction ceramics]. Stroitelniye Materialy [Construction Materials], 2, pp. 50-51. (in Russian) 